\title{
Alterations in Morphology and Aerobic Resistance of Rats Subjected to Different Physical Training Protocols
}

\author{
Alteraciones en la Morfología y Resistencia Aeróbica de Animales \\ Sometidos a Diferentes Protocolos de Entrenamiento
}

\begin{abstract}
Robson Chacon Castoldi' ${ }^{1,2}$; Alan José Barbosa Magalhães²; Guilherme Akio Tamura Ozaki²; Tatiana Emy Koike ${ }^{3}$; Thiago Alves Garcia ${ }^{2}$; Regina Celi Trindade Camargo ${ }^{3}$; William Dias Belangero ${ }^{2} \&$ José Carlos Silva Camargo Filho $^{3}$
\end{abstract}

CASTOLDI, R. C.; MAgAlHãeS, A. J. B.; OZAKI, G. A. T.; KOIKE, T. E.; GARCIA, T. A.; CAMARGO, R. C. T.; BELANGERO, W. D. \& FILHO, J. C. S. C. Alterations in morphology and aerobic resistance of rats subjected to different physical training protocols. Int. J. Morphol., 36(4):1472-1479, 2018.

SUMMARY: The objective of this study was to investigate the alterations in morphology and aerobic resistance of rats subjected to different physical training protocols. The study consisted of 55 rats of the "Wistar" breed, 100 days of age, over a period of 8 weeks. The animals were randomly distributed between four groups: control (CTLE); neuromuscular anaerobic (TAN); aerobic (TAE) and concurrent training (TCc). After four weeks, some of the animals were euthanized. The body mass index (BMI), Lee index (Lee), epididymal adipose tissue (TecAdp), body weight, and feed efficiency ratio (CoefAlim) were measured. The Anaerobic Threshold was determined by critical workload ( $7 \%, 9 \%$ and $11 \%$ of body weight). TAE and TCc training caused alterations in Lee and BMI, at four and eight weeks respectively (LeeTAE $=X: 2.86 \pm 0.08 ; \mathrm{X}: 2.89 \pm 0.07$ and LeeTCc $=\mathrm{X}: 2.85 \pm 0.05 ; \mathrm{X}: 3.00 \pm 0.09$ ). For the TecAdp, all groups presented a decrease, with the TCc value down after eight weeks (X:1.77 \pm 0.32$)$. Finally, TAN training improved the CoefAlim $(\mathrm{X}: 31.57 \pm 3.70)$ after the eight week period and the TCc presented the highest value for Lan $(\mathrm{X}: 7.10 \pm 0.80)$.

KEY WORDS: Morphology; Adipose Tissue; Body Mass Index; Body Weight; Physical Endurance.

\section{INTRODUCTION}

Excess weight is a major public health problem worldwide. Studies involving obesity have intensified in recent years due to the increasingpresence of individuals affected by this disease, assuming the proportions of a global epidemic (Ribeiro Braga et al., 2006). Poor diet combined with a sedentary lifestyle is a major factor in the onset of this pathology.

It is known that physical exercise increases caloric expenditure generated by mechanical work and contributes to the reduction of body fat (Bombarda et al., 2009; Calvez et al., 2011). Accordingly, researchers have explored physical activity and training programs intended to reduce excess weight and consequently obesity (Cheik et al., 2006). Finding an efficient way to combat this disease is now a challenge for researchers and practitioners of public health.

When dealing with the theme of physical training, there are several capacities which can be developed, depending on the specificity being worked on. Among these are aerobic capacity and physical strength. In this context, experimental studies are one possibility for testing the different models of training due to their easy application and high control of variables.

Researchers have found that the use of weight training could also be an effective way of combating obesity, since its implementation generates increased caloric expenditure and this fact contributes to the decrease in body fat mass (Ignacio et al., 2009). As a result, resistance and strength training have been used by health professionals, with the intention of resisting the obesity epidemic (World Health Organization, 2003).

Within this scenario, concurrent training (TCc) is an interesting option in the prescription of physical exercise. TCc uses distinct pathways in its implementation (aerobic/ anaerobic) and may contribute to increased caloric

\footnotetext{
${ }^{1}$ Department of Physical Education, Oeste Paulista University, Brasil..

${ }^{2}$ Department of Orthopedy and Traumatology, Campinas State University, Brasil..

${ }^{3}$ Department of Physiotherapy,Paulista State University "Júlio de Mesquita Filho" (Presidente Prudente Campus), Brasil.
} 
expenditure and consequently in reducing body fat. However, few studies have addressed this issue (Paulo et al., 2005), specifically investigating the use of TCc as a means of combating excess weight and reducing body fat mass.

Thus, the aim of the present study was to investigate the alterations in morphology and aerobic resistance of rats submitted of different physical training protocols.

\section{MATERIAL AND METHOD}

Animals. Fifty-five adult male Wistar rats (100 days) were used, acquired from the central Bioterium of Paulista State University (UNESP), Botucatu- SP Campus (Brazil). They were maintained at the bioterium of the Histology and Histochemistry Laboratory at the Faculty of Science and Technology, Presidente Prudente (FCT/ UNESP), in collective cages (polyethylene), with five animals per cage, with controlled temperature $\left(22 \pm 2{ }^{\circ} \mathrm{C}\right)$, humidity $(50 \pm 10$ $\%$ ) and a 12-h light/ dark cycle with access to food (standard laboratory chow) and water ad libitum. This study complies with the Ethics Committee on Animal Use (CEUA) of the Paulista State University "Júlio de Mesquita Filho" (Presidente Prudente Campus), protocol number 002/2011.
Experimental Groups. The study began with the separation of the animals into four training protocol groups $(n=55)$ : control (CTLE) [N=16], aerobic training (TAE) [N=13], anaerobic training (TAN) $[\mathrm{N}=13]$ and concurrent physical training (TCc) $[\mathrm{N}=13]$. After four weeks, the first collection of muscle tissue was performed. Thus, 22 animals were euthanized; 5 from the CTLE group, 6 from the TAE, 6 from the TAN and 5 from the TCc. In addition, 5 animals from the CTLE group which had been designated as the Base Line (BL) group had been euthanized at baseline (the beginning of the training period).

For the full eight week analysis, 23 animals remained, divided into six animals in the CTLE group, seven in the TAE, seven in the TAN and five in the TCc. There was a sample loss of three animals, one in the first four weeks and two in the final weeks of the experiment, leaving 20 animals for the final analysis (Fig. 1).

Except for the animals in the control group, the rats received adaptation to the equipment and liquid environment (10-20 min/day, 5 days aweek for three weeks, with overload and gradually increased duration) in advance of the training period (Manchado et al., 2006). The adjustment period reduced the stress produced by the liquid medium and the physiological changes resulting from physical training, but without generating significant adjustments in performance levels (Chimin et al., 2009).
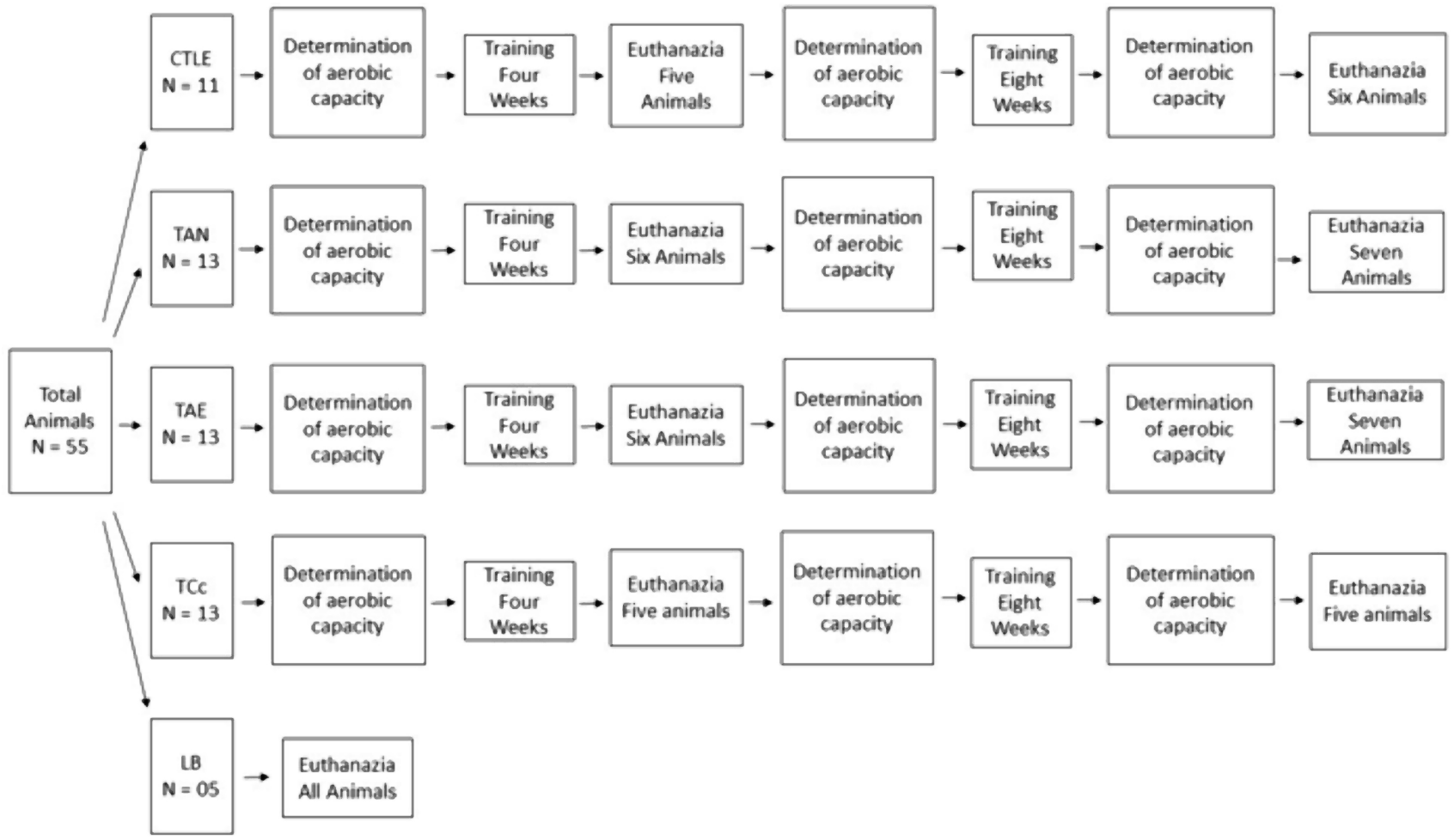

Fig. 1. Experimental Design. $\mathrm{CTLE}=$ control; TAN =anaerobic training; TAE $=$ aerobic training; $\mathrm{TCc}=$ concurrent physical training. 


\section{Experimental Group Explanation}

CTLE group: The animals remained free in their cages with unrestricted access to food and water.

TAE group: This consisted of 30 min of swimming, three days a week, in appropriate tanks, subdivided by PVC cylinders for individualization of the lanes, so that each animal trained individually. An overload, based on the aerobic capacity, was used, obtained from the Critical Workload (CCT), secured in the posterior region of the thorax by means of a pouch, specially adapted for this type of training. The intensity used corresponded to $70 \%$ of the anaerobic threshold (AT).

TAN group: This consisted of four series of 10 jumps, three days a week, in PVC cylinders specially modified for jumps in water $(50 \mathrm{~cm}$ long), with a water depth appropriate to the size of the animals ( $38 \mathrm{~cm}$ water). An interval of $1 \mathrm{~min}$ was established between each series of jumps, recorded by a stopwatch. The overload used was equal to $50 \%$ of the body weight of each animal and was accommodated in the anterior chest region by means of a specialized vest (De Mello Malheiro et al., 2009).

TCe group: This protocol was composed of a combination of the two models of physical training mentioned above. The exercise sessions were conducted in sequence (aerobic and anaerobic training) without an interval between sessions, three times a week. Each training session therefore was comprised of $30 \mathrm{~min}$ swimming (load set at $70 \%$ AT) and four series of 10 jumps with $50 \%$ overload of the body weight of each animal.

Determination of critical load (ccrit). To determine the Ccrit and anaerobic work capacity (CTA) the animals were randomly submitted to four different stimuli until exhaustion, with loads of $7 \%, 9 \%, 11 \%$ and $13 \%$ of body weight. Each session was separated by a minimum period of $24 \mathrm{~h}$. However, due to the failure of the animals to meet the criteria set out in the performance of the protocol (2-10 min of effort) with the stimulus of $13 \%$ of body weight, this load was removed from the linear fit.

The time limit (Tlim) for each effort was recorded. The points obtained from the relationship between load (\% BW) and the inverse Tlim (1/Tlim) were linearly adjusted so that the linear and angular coefficients corresponded to Ccrit and CTA respectively, adapted from Chimin et al., Hill (1993) and Marangon et al. (2002).

The Lee Index. The Lee Index was calculated for all animals using the relationship between the cubic root of weight (grams) and the muzzle-coccyx length $(\mathrm{cm})$ multiplied by 10 (Fig. 2A), in line with the study by Novelli et al. (2007).

Body Mass Index. The Body Mass Index (BMI) was calculated using the formula: Body weight (g) / [head-rump length (mm)] $\sum$ (Fig. 2A). This procedure was reproduced according to the models proposed by Novelli et al. and Sjögren et al. (2001).

Epididymal Adipose Tissue. After extraction, the epididymal adipose tissue (TecAdp) was weighed on a precision scale (Fig. 2B). For data analysis, we determined the percentage in relation to the weight of the animal using the mathematical formula: \{[TecAdp (g) x 100] / Weight $(\mathrm{g})\}$. This procedure was established as a way of correcting the difference in body mass between the animals (Shi et al., 2007).

Feed efficiency ratio. The ratio between the weight of the animal (Panimal) and the feed consumption, both in grams $(\mathrm{g})$, was established. Feed consumption was calculated by subtracting the leftover feed (SB) from the quantity of feed offered (RO). Thus, the resulting formula used was [Panimal/RO-SB], in accordance with the study by De Luca et al. (1996).

Statistical Analyzes. After obtaining the data, the following tests were performed: i the Shapiro-Wilk test to verify the normality of the data and determine parametric or non-parametric analysis (respectively); ii The One-way ANOVA or Kruskal-Wallis test with repeated measures to verify the differences between pre and post-training periods; iii The Bonferroni or Dunn post-hoc test to verify the differences between groups. All procedures assumed an error of $5 \%(\mathrm{p}<0.05)$.

\section{RESULTS}

A body weight increase was observed in all groups of animals, despite them already being considered adult animals (100 days old). In addition, there was statistical significance for this variable when comparing the three time moments (base, four and eight weeks). There were no significant differences between the groups of animals (Fig. 2A).

The aerobic capacity of the TAN and TAE groups improved. However, in the TCc group this capacity decreased at the four week moment and improved at eight weeks, 


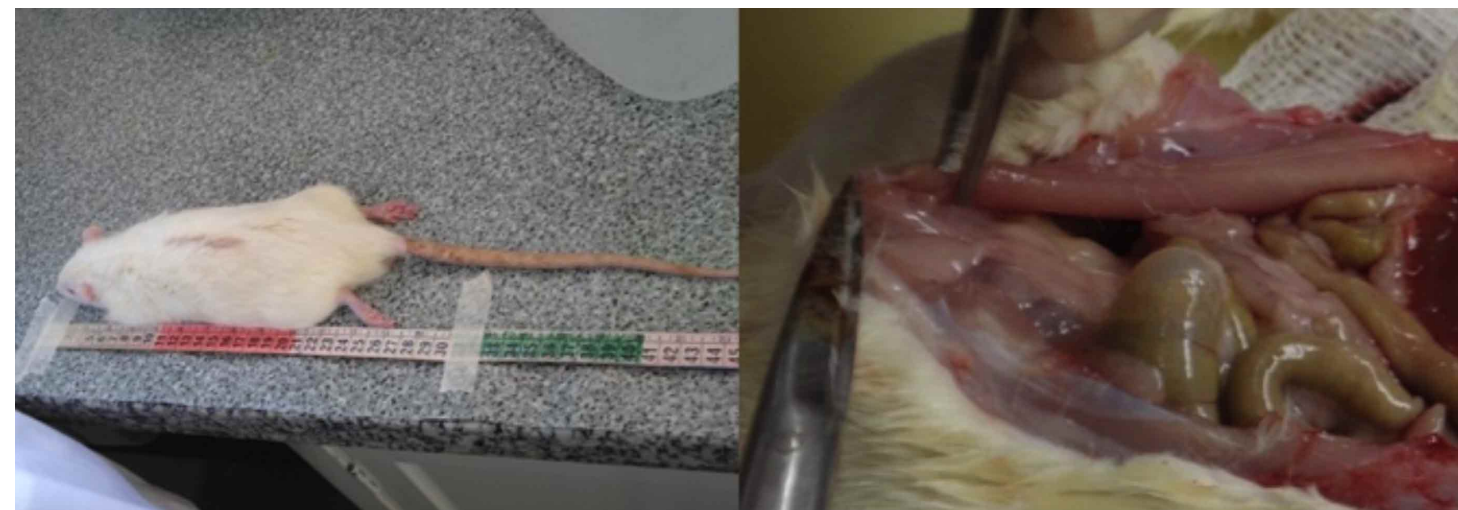

Fig. 2. Measure and collect of the samples. (A): Measure of the length. (B): Extraction of the epididymal adipose tissue.

furthermore, the efficiency of the CTLE group increased. A statistical difference was observed only in relation to time moments. The TCc group alone demonstrated a difference in relation to the CTLE group after four weeks (Fig. 2B).

It was also noticed that the lowest values for the Lee and BMI were presented by the TAE group. Furthermore, the values for the TCc group for these variables remained close to the mean values for the TAE group at the moments corresponding to four and eight weeks.(Figs. 3 and 4. A and B).
In relation to epididymal adipose tissue, it was observed that the groups of trained animals presented lower values for this variable. Furthermore, the TCc group presented the lowest percentage within the groups of trained animals (Figs. 3 and 4C).

Finally, it was found that the trained animals presented greater values for the coefficient of feed efficiency. It was also noticed that the TCc and TAE groups showed average values slightly below the other groups of animals, after four and eight weeks respectively (Figs. 2 and 3. D)
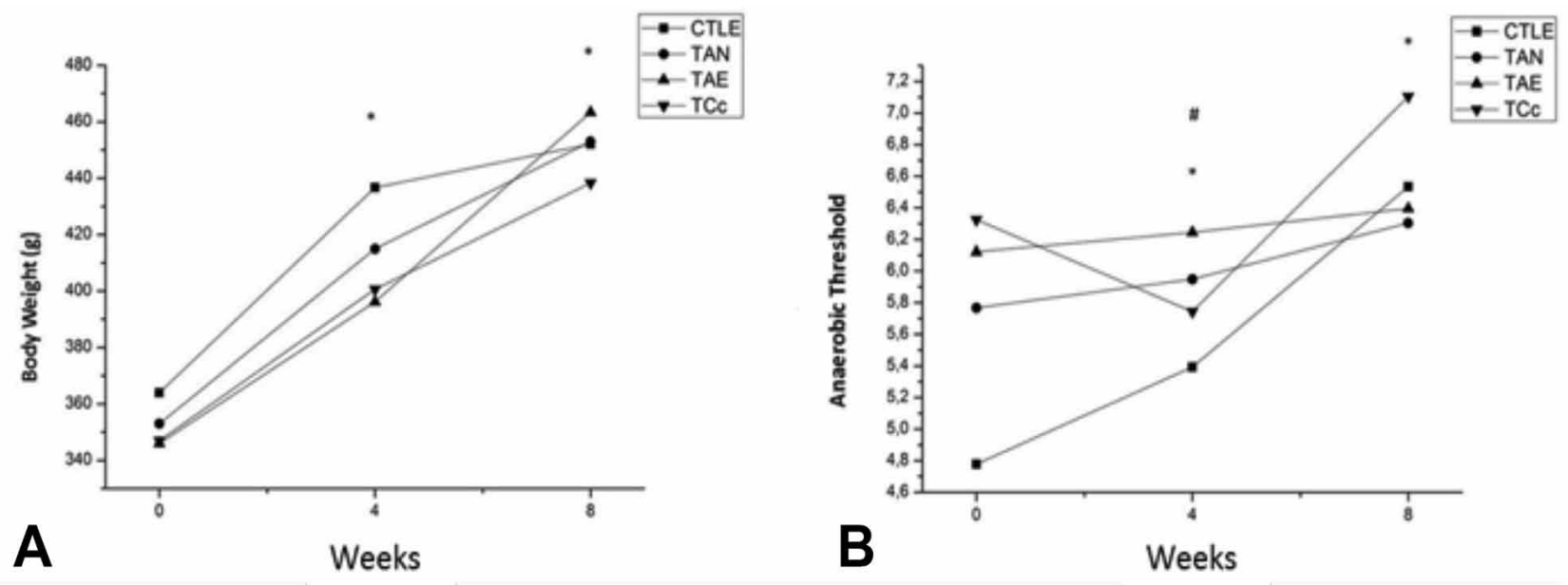

Fig. 3. Evolution of Body Weight (g) and Anaerobic Threshold of the groups during the experimental period. Legend: CTLE $=$ control; TAN =anaerobic training; TAE $=$ aerobic training; TCc $=$ concurrent physical training.(A) ANOVA One-Way for repeated measures with Bonferroni post-hoc test with an error of $5 \%(\mathrm{p}<0.05)$. $(*)$ A statistically significant difference at the four and eight week periods. There was no difference between the experimental groups at different times. (B) ANOVA OneWay for repeated measures with the Bonferroni post-test with an error of $5 \%$ ( $\mathrm{p}<0.05)$. (\#): Statistically significant difference at compared to the control group. (*): Statistically significant difference between the experimental groups after four and eight weeks. 

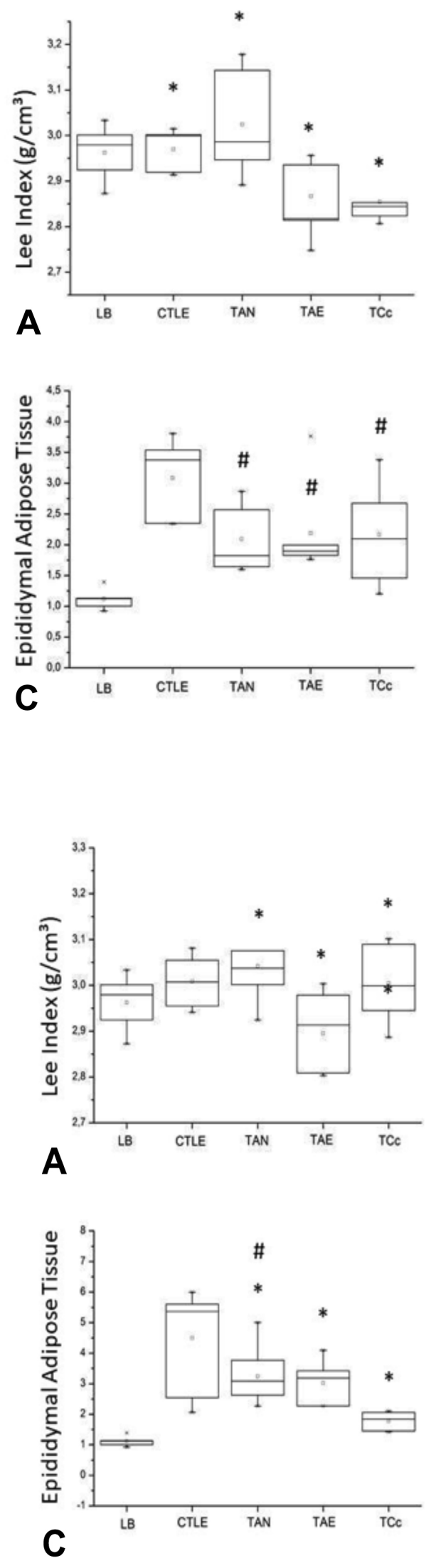
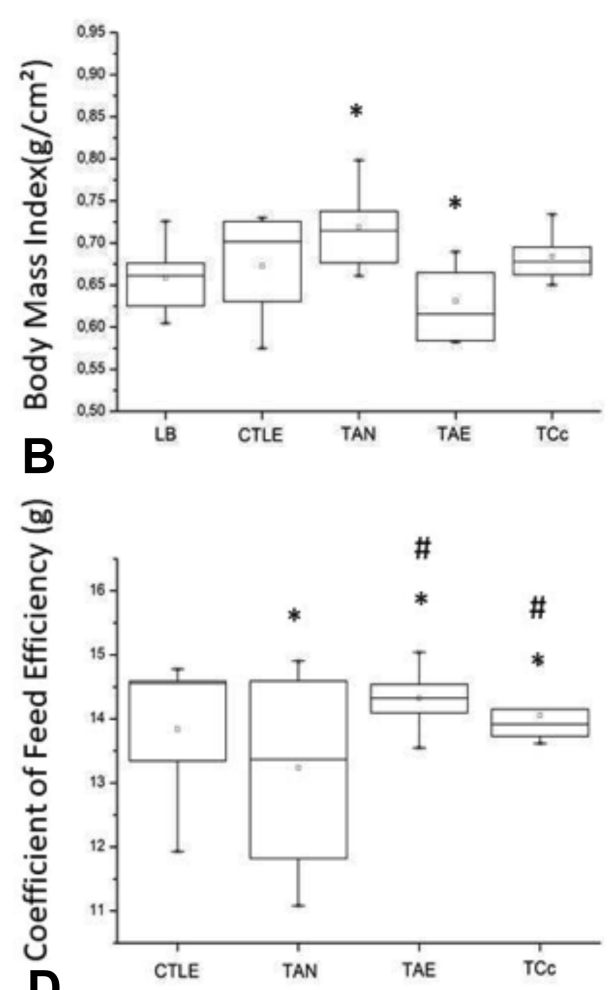

D
Fig. 4. Mean and Standard Deviation of the Lee Index (g/ $\left.\mathrm{cm}^{3}\right)$, body mass index $\left(\mathrm{g} / \mathrm{cm}^{2}\right)$, epididymal adipose tissue $(\mathrm{g})$ and Food Efficiency Ratio of the studied groups at the end of 4 weeks. Legend: $\mathrm{LB}=$ Base Line; $\mathrm{CTLE}=$ control; TAN = anaerobic training; TAE = aerobic training; $\mathrm{TCc}=$ concurrent physical training.(A) Lee Index; (B) Body Mass Index; (C) Epididymal Adipose Tissue; (D) Coefficient of Feed Efficiency. Note: (*): Mean. (): Median. Kruskal-Wallis with the Dunn post-test for the variable C. ANOVA One-Way with the Bonferroni post-test for the variables $\mathrm{A}, \mathrm{B}$ and $\mathrm{D}$. Both tests with an error of $5 \%$ $(\mathrm{p}<0.05) . \quad(*)$ difference between groups. (\#) difference between the experimental groups and the CTLE.
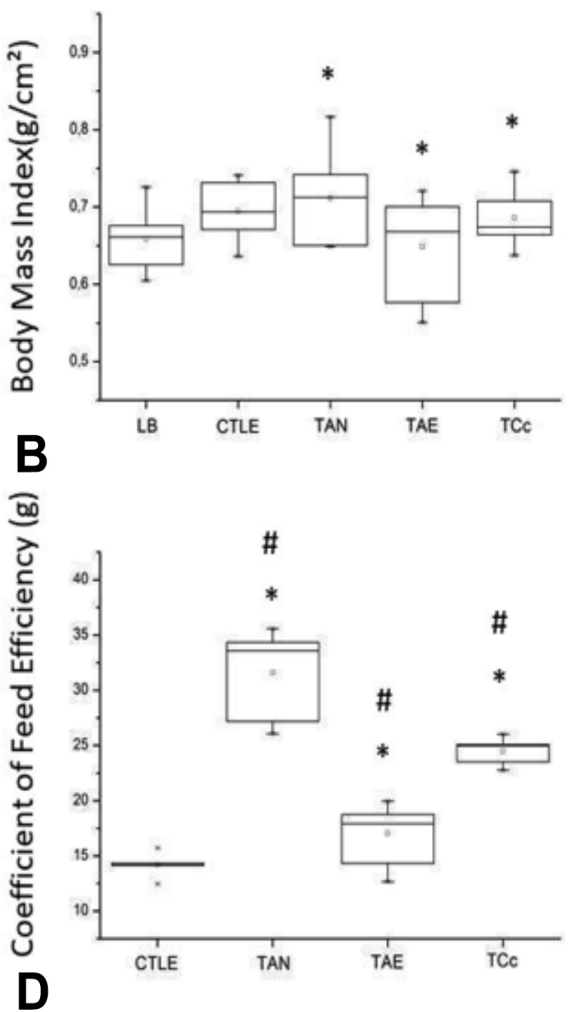

Fig. 5. Mean and Standard Deviation of the Lee Index (g/ $\left.\mathrm{cm}^{3}\right)$, body mass index $\left(\mathrm{g} / \mathrm{cm}^{2}\right)$, epididymal adipose tissue (g) and Food Efficiency Ratio of the studied groups at the end of 8 weeks. Legend: $\mathrm{LB}=$ Base Line; CTLE = control; TAN = anaerobic training; TAE = aerobic training; $\mathrm{TCc}=$ concurrent physical training.(A) Lee Index; (B) Body Mass Index; (C) Epididymal Adipose Tissue; (D) Coefficient of Feed Efficiency. Note: (*): Mean. (): Median. ANOVA One-Way with the Bonferroni post-test for the variables $\mathrm{A}, \mathrm{B}, \mathrm{C}$ and D. Tests with an error of $5 \%$ $(\mathrm{p}<0.05)$. (*) difference between groups. (\#) difference between the experimental groups and the CTLE. 


\section{DISCUSSION}

The present study aimed to analyse the effects of TCc, isolated strength training and aerobic training on the fat mass of Wistar rats. All protocols were found to be effective in reducing this variable. Moreover, TCc proved to be efficient in most of the studied indices, a fact which did not occur for aerobic capacity after four weeks.

The TCc group demonstrated greater aerobic capacity after eight weeks of physical training, with an average Anaerobic Threshold (AT) exceeding $7 \%$ of BW. However, it was found that after four weeks, there was a decrease in this capacity ( $6.3 \%$ to $5.7 \%$ of BW), an observation which indicated that the animals had not initially adapted adequately to TCc. However, after reassessment, and load adjustment, they adapted to the stimuli and aerobic capacity increased.

It is known that the specificity of the training can be a determinant in the adaptation process. In this sense, it is known that TAE produces an increased number of mitochondria, peripheral vasodilatation and an increase in the cardiac chamber, facilitating pumping of the blood and providing increased physical strength due to the improvement in oxygenation and nutrient transport (Castoldi et al., 2013).

The TAN is associated with increasing neurological innervation and recruitment of muscle fibers, promoting increased muscle contraction and, consequently, physical strength. Furthermore, the process of increasing crosssectional area, known as "muscle hypertrophy" can be encouraged. These adjustments are related to increased physical performance and muscle tone (Castoldi et al., 2016).

TCc is defined as the use of the forms of training described above, jointly and sequentially. Thus, theoretically, TCc could develop different adaptations which may promote increased strength and stamina (Leveritt et al., 1999; Paulo et al.; Castoldi et al., 2013, 2016).

However, findings in the literature demonstrate that there is still no consensus on the effects of TCc on physical capacity. Some authors have reported no effects from this type of physical training, principally when executed three times a week. Alternatively, in a review study (Leveritt et al.), all findings which presented an increase in physical capacity had been applied in a way that resembled the present study.

In one study (Bell et al., 2000), 45 individuals of both sexes were observed after 6 and 12 weeks of training. An increase in area of transverse section of fiber types I and II, was found, after 6 and 12 weeks in the isolated strength training group. In the TCc group, there was only an increase in type II fibers after 12 weeks. The authors concluded that the results support the theory that combined strength and aerobic endurance training can suppress certain adaptations to strength training and increase skeletal muscle capillarization.

This finding may explain the reduction in aerobic capacity at four weeks as the hypertrophic process of muscle fibers may have occurred, which affects buoyancy and hence performance in the liquid medium. It was noticed that at eight weeks this did not occur, similar to the above mentioned research (Bell et al.), where animals analyzed at the end of the experiment demonstrated improved Lan values.

The other groups of animals also demonstrated increases in this variable at four and eight weeks. It is noteworthy that the CTLE group presented increased Lan values. Studies using animals and swimming have shown that aerobic capacity may increase due to an increase in body mass and therefore body fat. In this sense, buoyancy can aid the animals in the swimming exercise (Voltarelli et al., 2003; de Araujo et al., 2009; Castoldi et al., 2013).

One study verified the influence of body fat on aerobic capacity in Wistar rats and concluded that fat mass improved as muscle mass decreased in this variable (Castoldi et al., 2016). Thus, the present study confirms the results of other studies performed in animals.

In relation to body mass there was an increase in this variable during the study period. This fact emphasizes that the animals may have gone through a natural process, as the CTLE group demonstrated similar increases to the other groups studied; in general, the animals presented a body mass index higher than that at baseline (340 to 420 grams).

The present study considered two different body mass indices commonly used in animal studies. The Lee Index (Lee) and Body Mass Index (BMI) were assessed during the performance of different protocols of physical training. It was observed that aerobic training (TAE) was more effective in reducing both the BMI and Lee, with the TCc group values close to those of the TAE. Conversely, the anaerobic training protocol (TAN), demonstrated lower efficiency for these two variables.

In another study (Nery et al., 2011), a significant correlation was found between the BMI and Lee, proving them effective in terms of ability to determine body mass and to act as predictors of overweight in rats. Furthermore, such tools can be considered as low cost and easily applied in this type of research. 
Studies have shown that aquatic aerobic exercise is an effective means of reducing body mass and therefore body indices (Calvez et al.). In addition, physical activity can be used as a non- pharmacological intervention for promoting health and quality of life (Bombarda et al.). Thus, TAE should be encouraged in cases of overweight and obesity.

The fact that TCc was less effective than TAE in decreasing the BMI and Lee, can be explained by the realization of isolated strength training, as the implementation of this form of training may have caused muscle hypertrophy and influenced the values assigned to the body indices since such measurements consider the body mass on a gross basis, without taking into account relative body fat.

In relation to the TecAdp, it was found thet all groups of animals presented similar reductions in the period after four weeks. However, after eight weeks, the TCc group showed a greater reduction when compared to the other groups. This fact supports the statement regarding the previous variable. It was noted that the values of the $\mathrm{BL}$ group were below the CTLE group at the two different periods, this fact demonstrates that the animals in the CTLE group suffered increased visceral adipose tissue over the course of the study.

There are a vast number of studies that demonstrate a strong correlation between high concentration of body fat and the emergence of pathological diseases. These events are mainly triggered by the location of adipocytes near the splanchnic region (thorax). According to Goularte et al. (2012), decreased caloric intake is a strategy in reducing obesity. In addition, exercise can be a used as a nonpharmacological intervention for combating excess body weight (Bombarda et al.).

Finally, the present study investigated the coefficient of feed efficiency (CFE) throughout the experiment, in the different animal groups. As euthanasia in the BL group was performed before the experimental period, this variable was not collected in this group.

The groups of animals which underwent physical training demonstrated CFE levels close to and above those of the CTLE group. However, after eight weeks of training, the TAN group presented the highest value for this variable. It appears that animals subjected to this form of training, show greater efficiency with regard to the aspect of weight gain / food intake.

Studies show that participating in physical exercise promotes decreased food intake and increases satiety (Wang et al., 2008; Hopkins et al., 2010; Nery et al.). Hence, physical training can help to reduce body fat by increasing energy expenditure and decreasing the quantity of food eaten.

This study contributes to the literature by determining the effects of TCc on the data mass of Wistar rats. However, it is worth noting as a limitation that this study did not measure the increase in muscle mass, which may influence the use of measurements and body indices, in addition, the anaerobic capacity was not evaluated. Future studies which include the measurement of muscle fibers (cross-sectional area) in conjunction with the variables used in the present study could contribute to the findings presented in this study.

\section{CONCLUSION}

We conclude that the different physical training protocols studied were effective in reducing fat mass and increasing aerobic capacity. Furthermore, TCc was shown to be an effective training model for these variables.

\section{ACKNOWLEDGEMENTS}

We would like to thank the Coordenação de Aperfeiçoamento de Pessoal de Nível Superior - CAPES and the Physical Therapy Department for their collaboration in developing this work.

CASTOLDI, R. C.; MAGALHÃES, A. J. B.; OZAKI, G. A. T.; KOIKE, T. E.; GARCIA, T. A.; CAMARGO, R. C. T.; BELANGERO, W. D. \& FILHO, J. C. S. C. Alteraciones en la morfología y resistencia aeróbica de animales sometidos a diferentes protocolos de entrenamiento. Int. J. Morphol., 36(4):1472$1479,2018$.

RESUMEN: El objetivo de este estudio fue investigar las alteraciones en la morfología y la resistencia aeróbica de animales sometidos a diferentes protocolos de entrenamiento. Se analizaron 55 ratas macho "Wistar" de 100 días de edad, durante un período de ocho semanas. Los animales fueron separados aleatoriamente en cuatro grupos: grupo control (CTLE); entrenamiento anaerobio neuromuscular (TAN); entrenamiento aerobio (TAE) y entrenamiento concurrente (TCc). Al término de cuatro semanas, algunos de los animales fueron sacrificados. Se midieron: índice de masa corporal (IMC), índice de Lee (Lee) y tejido adiposo del epidídimo (TecAdp), masa corporal y coeficiente de la eficacia alimentaria (CoefAlim). El umbral anaerobio (Lan) fue determinado por la carga crítica de trabajo (11, 9 y $7 \%$ de la masa corporal). El entrenamiento TAE e TCc provocó alteraciones de Lee e IMC, en los períodos de cuatro y ocho semanas, 
respectivamente (LeeTAE $=X: 2,86 \pm 0,08 ; X: 2,89 \pm 0,07$ y LeeTCc $=X: 2,85 \pm 0,05 ; X: 3,00 \pm 0,09)$. En relación a TecAdp, se observó una disminución en todos los grupos. Por último, el entrenamiento TAN mejoró en el período de ocho semanas para la variable CoefAlim (X:31,57 $\pm 3,70)$ y el TCc con un valor mayor de Lan $(X: 7,10 \pm 0,80)$.

PALABRAS CLAVE: Morfología; Tejido Adiposo; Índice de Masa Corporal; Peso Corporal; Resistencia Física.

\section{REFERENCES}

Bell, G. J.; Syrotuik, D.; Martin, T. P.; Burnham, R. \& Quinney, H. A. Effect of concurrent strength and endurance training on skeletal muscle properties and hormone concentrations in humans. Eur. J. Appl. Physiol., 81(5):41827, 2000.

Bombarda, J.; Melo, J. C.; de Souza, E. R.; Nóbrega, O. T. \& Córdova, C. Exercício abaixo do limiar anaeróbio aumenta as atividades fagocítica e microbicida de neutrófilos em ratos Wistar. J. Bras. Patol. Med. Lab., 45(1):9-15, 2009.

Calvez, J.; Fromentin, G.; Nadkarni, N.; Darcel, N.; Even, P.; Tomé, D.; Ballet, N. \& Chaumontet, C. Inhibition of food intake induced by acute stress in rats is due to satiation effects. Physiol. Behav., 104(5):675-83, 2011.

Castoldi, R. C.; Camargo, R. C. T.; Magalhães, A. J. B.; Ozaki, G. A. T.; Kodama, Y. F.; Oikawa, S. M.; Papoti, M. \& Camargo Filho, J. C. S. Concurrent training effect on muscle fibers in Wistar rats. Motriz Rev. Educ. Fis., 19(4):717-23, 2013.

Castoldi, R. C.; Coladello, L. F.; Koike, T. E.; Ozaki, G. A. T.; Magalhães, A. J. B.; Papoti, M.; Camargo Filho, R. C. T. \& Carmargo Filho, J. C. Effect of body composition on aerobic capacity of animals submitted to swimming exercise. Rev. Bras. Cineantropom. Desempenho Hum., 18(2):136-42, 2016.

Cheik, N. C.; Guerra, R. L. F.; Viana, F. P.; Rossi, E. A.; Carlos, I. Z.; Vendramini, R.; Duarte, A. C. G. O. \& Dâmaso, A. R. Efeito de diferentes frequiências de exercício físico na prevenção da dislipidemia e da obesidade em ratos normo e hipercolesterolêmicos. Rev. Bras. Educ. Fís. Esporte, 20(2):121-9, 2006.

Chimin, P.; Araújo, G. G.; Manchado-Gobatto, F. B. \& Gobatto, C. A. Critical load during continuous and discontinuous training in swimming Wistar rats. Motricidade, 5(4):45-58, 2009

de Araujo, G. G.; de Araújo, M. B.; DAngelo, R. A.; Manchado, F. B.; Mota, C. S. A.; Ribeiro, C. \& de Mello, M. A. R. Máxima Fase estável de lactato em ratos obesos de ambos os gêneros. Rev. Bras. Med. Esporte, 15(1):469, 2009.

De Luca, R. R.; Alexandre, S. R. \& Marques, T. Manual para técnicos em bioterismo. São Paulo, Winner Graph, 1996.

De Mello Malheiro, O. C.; Giacomini, C. T.; Justulin, L. A. Jr.; Delella, F. K.; Dal-Pai-Silva, M. \& Felisbino, S. L. Calcaneal tendon regions exhibit different MMP-2 activation after vertical jumping and treadmill running. Anat. Rec. (Hoboken), 292(10):1656-62, 2009.

Goularte, J. F.; Ferreira, M. B. \& Sanvitto, G. L. Effects of food pattern change and physical exercise on cafeteria diet-induced obesity in female rats. $B r$. J. Nutr., 108(8):1511-8, 2012.

Hill, D. W. The critical power concept. A review. Sports Med., 16(4):237-54, 1993

Hopkins, M.; King, N. A. \& Blundell, J. E. Acute and long-term effects of exercise on appetite control: is there any benefit for weight control? Curr. Opin. Clin. Nutr. Metab. Care, 13(6):635-40, 2010.

Ignacio, D. L.; Frankenfeld, T. G. P.; Fortunato, R. S.; Vaisman, M.; Werneckde-Castro, J. P. S. \& Carvalho, D. P. Regulação da massa corpórea pelo estrogênio e pela atividade física. Arq. Bras. Endocrinol. Metab., 53(3):310-7, 2009.
Leveritt, M.; Abernethy, P. J.; Barry, B. K. \& Logan, P. A. Concurrent strength and endurance training. A review. Sports Med., 28(6):413-27, 1999.

Manchado, F. B.; Gobatto, C. A.; Contarteze, R. V. L.; Papoti, M. \& Mello, M. A. R. The maximal lactate steady state is ergometer-dependent in experimental model using rats. Rev. Bras. Med. Esporte, 12(5):25962, 2006.

Marangon, L.; Gobato, C. A.; Mello, M. A. R. \& Kokubun, E. Utilization of an hyperbolic model for the determination of critical load in swimming rats. Med. Sci. Sports Exerc., 34(5):S149, 2002.

Nery, C. S.; Pinheiro, I. L.; Muniz, G. S.; Vasconcelos, D. A. A.; França, S. P. \& do Nascimento, E. Murinometric evaluations and feed efficiency in rats from reduced litter during lactation and submitted or not to swimming exercise. Rev. Bras. Med. Esporte, 17(1):49-55, 2011.

Novelli, E. L.; Diniz, Y. S.; Galhardi, C. M.; Ebaid, G. M.; Rodrigues, H. G.; Mani, F.; Fernandes, A. A.; Cicogna, A. C. \& Novelli Filho, J. L. Anthropometrical parameters and markers of obesity in rats. Lab. Anim., 41(1):111-9, 2007.

Paulo, A. C.; de Souza, E. O.; Laurentino, G.; Ugrinowitsch, C. \& Tricoli, V. Efeito do treinamento concorrente no desenvolvimento da força motora e da resistência aeróbia. Rev. Mackenzie Educ. Fis. Esporte, 4(4):145-54, 2005.

Ribeiro Braga, L.; Rostom de Mello, M. A. \& Gobatto, C. A. Exercício contínuo e intermitente: efeitos do treinamento e do destreinamento sobre a gordura corporal de ratos obesos. Arch. Latinoam. Nutr. 54(1):58-65, 2004.

Shi, H.; Strader, A. D.; Woods, S. C. \& Seeley, R. J. The effect of fat removal on glucose tolerance is depot specific in male and female mice. Am. J. Physiol. Endocrinol. Metab., 293(4):E1012-20, 2007.

Sjögren, K.; Hellberg, N.; Bohlooly-Y, M.; Savendahl, L.; Johansson, M. S.; Berglindh, T.; Bosaeus, I. \& Ohlsson, C. Body fat content can be predicted in vivo in mice using a modified dual-energy $\mathrm{X}$-ray absorptiometry technique. J. Nutr., 131(11):2963-6, 2001.

Voltarelli, F. A.; Nunes, W. M. S.; Silva, A. R. S.; Romero, C. E. M.; Garcia, D. R.; Paoli, J. R.; Santhiago, V.; Gobatto, C. A. \& Mello, M. A. R. Determinação do limiar anaeróbio em ratas obesas tratadas com glutamato monossódico [MSG]. Rev. Logos., 11:84-92, 2003.

Wang, J.; Chen, C. \& Wang, R. Y. Influence of short- and long-term treadmill exercises on levels of ghrelin, obestatin and NPY in plasma and brain extraction of obese rats. Endocrine, 33(1):77-83, 2008.

World Health Organization (WHO). Artificial tanning sunbeds. Risks and guidance. Geneva, World Health Organization, 2003. Available from: http://www.who.int/uv/publications/en/sunbeds.pdf.

Corresponding author:

Robson Chacon Castold

Roberto Simonsen Street, 305

19060-900 - P. Prudente, SP

Presidente Prudente City - SP,

BRAZIL

\section{E-mail:castoldi_rc@yahoo.com.br}

Received: 23-03-2018

Accepted: $24-07-2018$ 